\title{
Resources Control: A Panacea for Sustainable Peace and Development in the Niger Delta Region of Nigeria
}

\author{
Kingdom Sunday Mboho, Ph.D.; Ekaete Rapael Udoh, M.Sc.; \\ Unwana-Abasi Sunday Udo, M.Sc. \\ Department of Public Administration Faculty of Social and Management Sciences Akwa Ibom State University \\ Nigeria \\ Department of Political Science Faculty of Social and Management Sciences Akwa Ibom State University \\ Nigeria
}

Department of Public Administration Faculty of Social and Management Sciences Akwa Ibom State University Nigeria

\begin{abstract}
If there is any issue that is widely discussed by majority of people and yet ignorantly misunderstood by many is the issue of resource control. With a greater number of Nigerian skill picking the pieces and making the head and tail of the supresne court judgment on resource control the height types of public discourse on the subject is by now well understood. This study was primarily focused on resource control as a panacea for sustainable peace and development in Niger Delta Region of Akwa Ibom State with emphasis on how it affects their quality of people living condition. The study adopted survey design, and was conducted in the 3 Local Government Areas in each of the state using a sample of 100 respondents, randomly selected from 3 Local Government Areas in each of the senatorial districts. A total of 9 Local Government Areas and 36 villages were used as sample area of the study. The analysis of the data was done using the independent chisquare $\left(x^{2}\right)$ to test the research hypotheses. The finding reveals that there is a relationship between resource control and sustainable peace, development in the region. The study recommends that, it is imperative to increase the amount of money being given to states of Niger Delta as derivation and the state governors should ensure that the money is used to better the lots and welfare needs of the people at the grass roots.
\end{abstract}

Key Words: Resources Control, Sustainable Development, Rural Development, Economic Development, Deprivation and Federalism

\section{Introduction}

The term "Resource Control" mean different things to different people with a common understanding that whoever controls the resources, controls the means of wealth. Some talked of it in absolute terms while others see it simply as having a fair share in the resource produce in their land. The south-south region of Nigeria is a rich part of the country but majority of her people are poor although evidently endowed, she has been unable to transform its rich resources into economic development to commensurate with her level of endowment. Thus, the vast majority of her people especially in Niger Delta live below the poverty line with the reason that this region affairs is attributed to the fact that economic development have not achieved the desire result where sound economic polices were enunciated, implementation has been shoddy and has led to stunted economic, sustaining peace and development growth. The different between the rural poor and urban poor becomes insignificant (Awa, 2008).

The challenges facing Niger Delta region since the creation has been inability to generate wealth, but by every consideration, the Niger Delta region is wealthy. The challenge has become one of the effective and efficient management of its wealth to the advantage of a larger fraction of its citizenly. In attempt made so far to meet this challenge, Governor Attah led administration has experienced a number of Obnoxious economic polices and degrees enunciated by the federal government to pull the state down. It is then necessary to briefly review the states experience on 13 percent derivation formular, the introduction of the on-share/off-shore dichotomy etc. in order to gain a tear and the basis for hope under this political dispensation, (Akpan, 2001).

One may think naively, that the federal government was confounded as to the application of section 162 (2) of the 1999 constitution concerning the 13 percent principle of derivation of oil producing states were derived payment of revenue from off-shore resources. But with the recent case instituted by the federal government against the states at the Supreme Court the denial to pay revenue from off-shore oil at the beneficiary states is obvious as willingly premeditate. As the matter is in the court for public interest, it is thought proper its highlight have the laws that have affected ownership of oil mineral derivation principle and its application. 
The various laws passed between 1914 and 1948, for example, the mineral Oil Act 1914, the petroleum Act 1918, mineral Act 1946 and mineral Act 1948 vested ownership of the petroleum in the state, at the time, they crown. The mineral Act of 1946, for example, provided "that the entire property in control of mineral oils, under or upon any lanes in Nigeria and all wires, stream and water sources throughout Nigeria is and shall be vested in the crown". But in the allocation Revenue, the Nigeria (constitution) order in 1980, that ownership in section 134(1) shall be paid by federation to each region in charging the Northern and Southern region of the state a sum equal to $50 \%$ of the contraction in that region. It further provided in section 734 (6) that for the purposes of the section of the continental shelf, the region shall be deemed fit to be part of that region, (Enyim, 2001).

The position of the law above as to ownership and revenue allocation concerning out minerals was maintained and continued till the 1963 Nigeria constitution. During those periods, there were no dichotomy of on-shore/off-shore and by the interpretation of continental shelf; any area on off-shore derived was never a problem to determine. Even when states were created, as we then had mid Western State, Cross River State and River State, littoral oil producing state in the country encounter no problem (Obi, 2010).

During the Gowon's administration, distinction of on-shore and off-shore as to what percentage is potable to the states was introduced. It did not obfuscate the country as to which state the off-shore revenue was given to, (Obi, 2010). Following this practice and proceeding in the last thirteen years, there was no problem as to whoever the off-shore oil is derived from, as the continental shelf of a revenue region (now state) is derived to be part of that region (state). The international law, a coastal state exercise light over the continental shelf by virtue of its sovereignty over land, of which the shelf is the natural prolongation. This is in accords with the Truman proclamation which regarded continental shelf as an extension of the landmass of the coastal region.

\section{Concepts Of Resource Control}

For projects to contribute to the development of host communities, government, private companies, local communities and non-governmental organizations that represent them must be committed to work together as partners. Although each has different responsibilities, the partners must have mutually agreed objectives, share responsibilities and reciprocal obligations, (Adisa, 2008).

The role of government is to provide an appropriate policy framework which clearly delineate the division of responsibilities between the public and the private sector, determine how project's revenue are used, monitor and evaluate project, deliver education, health care and other social services, provide security and develop infrastructure for planning up stream development projects, Awa, (2008). Project development must give attention to social concerns, acknowledge all stakeholders, identify risk and opportunities, assess impact, provide for public involvement in project design and implementation, and develop mechanism for resolving conflict and evaluating project effectiveness.

NGO's can provide valuable input and show work by side with government official and to the communities they represents (Midweek Pioneer, April 16, 2012).

\section{Social Effect Of The New Law On Economic Development}

The effect of this law- the obnoxious on-shore/off-shore oil dichotomy is to suggest that, even though the Department of Petroleum Resources (DPR) has declared Akwa Ibom State the largest oil producing state in Nigeria, because all of its production $(100 \%)$ is off-shore, the state shall get no direct benefit from derivation. Instead the total value of it oil production will be paid into the federal account.

So Akwa Ibom State is left the pollution, the degradation of its environment, the destruction of fishing industry, the health problems, but with no benefit at all from deviation (Akpe, 2010).

Let the impression not be given that after we had formed ourselves into the matrix that binds the belligerent majority tribes of Nigeria into the country, the only reason that we are wanted in the union is so that, we can be robbed and all our resources catered away in a manner that even the worst external colonialist could not have contemplated for those states who expect to benefit financially from this judgment, we suggest that the read Justice Ogun dare's statement with more discernment.

$\mathrm{He}$ is quite categorical that "for a state to qualify for this allocation (derivation) funds from the federation account, the natural resources must have come from within the boundaries of the state, which is the resource must be located within the state. He further states that "this is so because at common law, the seashore or fore-shore (both means the same thing) belongs to the crown and according to him, Federal Government not the federation is the inheritor of the crown, so we may be misled to support this injustice for selfish reason only to find that, the only beneficiary is the over bloated federal government as distinct from the federation. Let not the South South to derive into thinking that they are not affected because their oil or gas is on-shore. Take a look at the Nigeria oil map and note that everything is moving off-shore. If we accept this injustice today, what will be our fate tomorrow such a diabolical thing could only be contemplated to a 
psalmist in the belief that many are the trials of the just man but item all, the Lord will rescue him (Alamieyesiegha, 2010).

\section{Problems Of Resource Control}

Resource control is a burning issue of discourse in Nigeria today. And rightly so because this concept straddles the ethnical, the macro-economic and the political and does address the key question of whether Nigerians should be citizens or subjects to and slaves in their own country. A Nigerian citizen is called upon everyday, from the womb to the tomb, to participate in determining what is produced, how and for whom in Nigeria, but a Nigerian subject and slave takes dictations from home and especially from the west, in regard to what is to be produced, how for whom in Nigeria, (Okigbo, 2004). This is why the ethical dimension of the concept of resource control would like us Nigerians to address the question of all of us Nigerian or just whether it is the commodity naira/private-sector-naira/or the debt naira/public sector-naira that we should use in distributing and its records a plenty among us Nigerian.

So, the point which the current engagement by Nigerian with the concept of resources control makes, is that, we Nigerian say that, it is of atmost and urgent importance to us Nigerian, that we find and begin to work such a domestic structure of resource use that makes citizens all and subjects more of us Nigerians in our country Nigerian, (Alozie, 2010).

What this translates to in macro-economic language was clearly spelt out in the researchers which the Belgo-American economist, Robert Triffin, did on Latin American economies in the 1940s. For, Traffin did see from his field studies, that any economy grows steadily in real sector output, or GDP, only when its money supply structure, or financial circulation of money; has little or no foreign currency input but that as foreign currencies begin to displace a home currency as the medium of exchange in an economy so will inflation and steady decline in real sector output, or GDP, overtake the economy, (Waheed, 2010).

So, what Traffin is saying is that as the money supply of an economy comes increasing from local money factory so does the economy experience the growth in the GDP with less information, but as its money supply comes increasing from a foreign money factory, so does it being experience decay in GDP with more inflation.

\section{Solution To The Problems Of Resources Control}

Macro-economic recognizes two competitive concept of the monetary unit. The demand side or debt, money and the other is the supply side or commodity money, and the distinction between the two is very clear and is as follows:

Demand-side money, by putting an economy's public sector and its budget at the centre of its money supply management, sees it as its primary objectives of service the short-term but rolling finding needs of the deficit-financing public sectors. This is how and why the concepts of treasury bill rate, TBR, and minimum rediscount rate, MRR become central to the debt-banking regime of any economy that is under the heel of fractional reserve central banking (Salau, 2009). Supply-side money, in contrast hereto, puts the private sector of an economy at the centre of its money supply management. It thereby, goes out every day to service the private sector entrepreneur with seed capital, working capital and growth capital. This is how and why profit and loss circulation under the heel of fractional reserve centres banking.

The difference between the public sector financing and private sector financing objectives of the demand-side and supply-side concepts of money, respectively, heads naturally to differences in how these competing concepts of money spread out industrial activities on the ground in any economy and also how they distribute the economic power between locals and foreigners to determine what is produced, how and for whom in the economy (Salau, 2009).

In effect as the $\mathrm{CBN}$ embarks on a hand-on gold demonetization naira policy, so will equity naira seek out rural value-adding end-users in the Nigerian country-wide network of back-to-back stock and commodity exchanges. This is how the naira is enabled to bestride the Nigerian financial and industrial moneyflows and thereby transact at least $80 \%$ of Nigeria's annual GDP.

Finally, resource control is the heart of micro-economics and of politics. It is the entire womb to the tomb, at the beginning, at the centre and at the end of every aspect of Nigeria's public policy. It is, indeed, all about justice, all about social inclusion and all about living every Nigerian his rightful due at all times. And come to think of it, resource control is all about taking in Nigerian bunk to out equalitarian and communitarian roots. It is simply the bottom-to-top market development of Nigeria (Waheed, 2010).

\section{Resource Control Issue And Appropriate Federalism In Nigerian}

The argument of resource control is that if we reduce it to its bores, bones it will be simplified, self serving and hollow in places. Nigeria produces oil and collects the bulk of its VAT from a limited number of states. These states should be allowed to take all the oil royalties and VAT revenue and only pay voluntary 
tributes to the federal or central government on a basic that should be determined mostly by the states almost unilaterally.

The federal government should keep only whatever that all conquering states in their magnanimity considered adequate for purposes of maintaining whatever residual functions the states (mostly the seventeen southern states). Think it is good enough to perform. In essence, the contingent on the magnanimity of the states.

Beyond that, the plight of the federal or central government and all of us should be determined at some big conference to be convened by some phantom authority with attendance drawn, arbitrary from among those who make noise in the newspaper and bang table on TV or shout in radio stations (Amuta, 2011).

If the informing-argument is followed to its logical tragic-comic conclusion, the advocates of true federalism and resource control will need to tell us who will protect the states from their own excesses or from their ambitious governors. Some of whom are already behaving like tiny war Lords. For the advocates or true federation and resource control, the acts of financial recklessness and criminal insensitively are only a foretaste of what will happen to the dividends of resource control and true federalism in Nigeria; if indeed they were legally viable and constitutionally desirable prepositions, but they are not, Adisa (2009).

Without doubt, there is fundamental illogic and injustice in the present revenue encouragement in the country as it concerns ownership of land and the resources that lie underneath and above it. Under the present arrangement, a man builds his house on his ancestral land, but whatever minerals that he underneath that house belong to the federal government which his house stands is subject to the Whims of the state government under the land use Decree. When the oil companies find out under your hurt, they sign, ahead and pull down your house pay you a pittance and despoil your environment and leave you in the dark ages of human civilization. Now the state went to replace the federal government in this exploitative arrangement.

According to Amuta, (2011), the resource control argument is therefore as flowed as the current regime, which it is out to dust. It seeks to replace federal exploitation with state greed addressing the fundamental inequity and violation of the rights of those whose individual, family and communal land provides the bulk of the resources that oils the machinery of the Nigerian states. The way out is to restore the proprietary rights individuals and communities to their lands by abrogating the land use Decree through an act of the National Assembly by so doing, oil companies will have to sign up with the owners of the land on which they must operate and pay them appropriate royalties.

The real resource control, battle waiting to be waged in-effect, is that which will guarantee individuals and their immediate communities the fullest benefit of the resources that lie above or beneath their very lands. We will have achieved justice and equity the day we stop greedy federal and state governments from seizing in individual lands and singing away the mineral rights to foreign companies without the consent of the landowners, (Awa, 2008).

\section{Methodology}

The study was based on descriptive survey design, since it enabled the researcher to collect data from respondents without imposing any condition on them. The respondents were asked information through questionnaire as the research instrument. The design for this study outlined stages and the procedures need in order to accomplish the goals of the investigation, such procedures included the identification of the population, selection of sample size, selection of respondents, data collection and analysis. It was conducted in the three (3) senatorial districts of the state using a sample of 100 respondents, randomly selected from 3 Local Government Areas in each of the senatorial districts. A total of 9 Local Government Areas and 36 villages were used as sample areas and the population comprises titled chiefs, other indigenes, and residents of the communities. Data collected from both the primary and secondary sources through the use of questionnaire, books, journals, among others, were collected, presented and analyzed with the help of independent chi-square $\left(x^{2}\right)$.

\section{Data Presentation And Interpretation Of Results}

Data were collected mostly through the use of questionnaire. Copies of the questionnaire study sites selected for the study. These section analyses the data collected and test the formulated hypothesis for significance.

\section{Test Of Hypothesis One}

$\mathbf{H}_{\mathbf{0}}$ : $\quad$ There is no relationship between resource control and sustainable peace in the region.

$\mathbf{H}_{\mathbf{i}}$ : $\quad$ There is a relationship between resource control and sustainable peace in the region. 
Table 1: Response Pattern

\begin{tabular}{|c|c|c|c|c|c|c|}
\hline Department & \multicolumn{2}{|c|}{ Variables } & \multirow[t]{2}{*}{ Total } & \multirow[b]{2}{*}{$x^{2}$ cal. } & \multirow[b]{2}{*}{$x^{2}$ table } & \multirow[b]{2}{*}{ Remarks } \\
\hline & Agreed & Disagreed & & & & \\
\hline Personnel & 30 & 20 & 50 & & & \\
\hline Treasury & 20 & 10 & 30 & & & \\
\hline Payroll & 10 & 10 & 20 & 2.80 & 5.99 & Significant \\
\hline Total & 60 & 40 & 100 & & & \\
\hline
\end{tabular}

Source: Field survey 2013.

\section{Result}

Data were collected and used in the presentation, testing and analysis of data. Testing of the formulated hypothesis implies that there is a significant relationship between resource control and sustainable development in the region.

\section{Conclusion}

When ordinary people and their environment becomes victims of disruptive economic expansion without adequate protection or provision of alternative means to improve their social and economic circumstances, they will remain vulnerable.

Therefore, the need to broaden the social responsibilities and performance of the oil industries in order to maintain economic progress with environmental balance should be a matter of compulsion. In Nigeria today, contrary to the counsel of the late Sir Ahmadu Bello, those who are derived the benefits of oil and gas exploration and development are exclusively shouldered with, the burden. It is not in the national interest for the Supreme Court to be a court of first instance. Admittedly, this has helped to shorten the length of time it takes to settle or resolve the contentious constitutional disputes between the federation and the state or between state or local government. But as a court of first instance, any mistake it makes would be numerical to the peace and security of the nation.

There is need as a matter of fact to put in place the reverent statutes as the political and economic future of some of the states is now in jeopardy. We, as Nigerian must now understand that, we have no alternative to the national conference since the judgement will necessarily involve an amendment to the constitution.

\section{Recommendations}

After exhaustive research on the contention issues of resource control, true federation, social justice and Democratic Stability in Nigeria, the following recommendations were made in the study:

1. The agitation for the control of oil minerals buried in the bowel of their land is legitimate demand by the people of the south-south or the Niger Delta region.

2. The nation makes billons of naira on a daily basis from exploitation of oil minerals in the Niger Delta , no concessions or pragmatic efforts have been made on the part of successive governments in Nigeria to cushion the effects of environmental degradation, destruction eco-system, petition of water which is the source of water supply for domestic chores and aquatic activities in the Niger Delta.

3. It is conservable, unimaginable, irreconcilable and unacceptable that the people of south-south where the nation desires in about eighty five percent $(85 \%)$ of her animal income live in abject poverty without good network in roads and have no access to social facilities such as electricity, portable drinking water, health, medical care and education.

4. The people themselves should constitute the vanguards that monitor efficient and effective utilization of the money by the governors for their own goods.

5. It is imperative to increase the amount of money being given to states of Niger Delta as derivation, the state governors should ensure that the money is used to better the lots and welfare needs of the people at the grass roots.

6. There is no where in the world where the area that generates the income that sustains a country does not benefit more than the other areas but the case of Nigeria is an anathema and the federal government should be blamed while this neglect and denial.

\section{References}

[1]. Adisa, T. (2009). Resolute on Resource Control: Seventeen Southern Governors Resolved to forge ahead with the guest for Resource Control. Punch Newspaper, Tuesday 3, April 10, Lagos. 17(1086): 12.

[2]. Akpe, S. (2010). Arewa, South Leaders Meet-over Resource Control. Punch Newspaper, Saturday, February 24, Lagos: 17(1043):1-2.

[3]. Alamieyeseigha, D. (2001). Resource Control: We'll fight beyond the Supreme Court. Punch Newspaper, Sunday, February 24, Lagos. 17(1043):15. 
[4]. Alozie, P. (2010). Ethnic Nationalism in Nigeria. In training the Wilderness: The $1^{\text {st }}$ two years of Obsanjo Administrative, Reachout Investment Ltd, Lagos.

[5]. Amuta, C. (2011). Resource Control and Appropriate Federalism. The Vanguard Media Ltd, Lagos.

[6]. Awa, E. O. (2008). Issues in Federalism Benin City, Ethiopia Publishing Corporation.

[7]. Bisong, O. E. (2001). Resource Control Controversy. In training the Wilderness: The $1^{\text {st }}$ two years of Obsanjo Administration, Reachout Investment Ltd, Lagos.

[8]. Enyim, O. E. (2001). Resource Control: Ohanaeze Faults Southern Governors. Punch Newspaper, Wednesday, January 17, Lagos. $17(18,038): 186$

[9]. Federal Republic of Nigeria, (1978). The Constitution of the Federal Republic of Nigeria, Kaduna Newspaper Ltd

[10]. Federal Republic of Nigeria, (1991). National Rolling Plan, 1991-93. National Planning Commission, Abuja.

[11]. Federal Republic of Nigeria, (1996). National Rolling Plan, 1996-97. National Planning Commission, Abuja.

[12]. Federal Republic of Nigeria, (1997). National Rolling Plan, 1992-99. National Planning Commission, Abuja.

[13]. Federal Republic of Nigeria, (1999). The Constitution of the Federal Republic of Nigeria, 1999. Vol. 86 (27). Lagos: Federal Government Press may page A 960.

[14]. Obi, S. (2010). Let there be Resource Control: The vanguard, Monday, April 2, Lagos 17(4721):28.

[15]. Okigbo, P. (2004). Revenue Allocation in Nigeria, (1945-1960). A Historical Survey in Essays in the Public Philosophy of Development. Vol. 2 Change and Crisis in the Management of the Nigeria economy. Fourth Dimention Publishing Co. Ltd, Enugu. 